\title{
"With a View to Publication": The Unfinished Documentary History of World War I
}

\section{S. Matthew Cheser}

Au cours de la première décennie qui a suivi la Première Guerre mondiale, la marine américaine s'est efforcée d'exposer son rôle dans le conflit par le biais d'une histoire officielle. Le projet a d'abord été confié à l'Office of Naval Records and Library [Bureau des archives navales et bibliothèque] de la marine et, plus tard, à son directeur le capitaine (retraité) Dudley Knox. Habile administrateur et leader, le capitaine Knox a dirigé le projet au cours de pénuries de main-d'œuvre et de périodes de négligence fiscale. Bien que l'histoire documentaire ne se soit pas rendue au stade de l'imprimerie, le Bureau des archives navales et sa bibliothèque ont réalisé, par leurs travaux, un impressionnant fonds documentaire de grande importance et posé les fondations de l'histoire de la marine moderne.

The preface of the "Official Records of the US Navy in the World War," dated 14 June 1929, opens with the declaration, "The collection of papers printed herein cover every aspect of the war at sea from the standpoint of the United States." Despite this introduction, the preface and the thousands of papers that follow were never printed. They exist only as originals at the National Archives in Washington DC and duplicated on microfilm reels located at the Navy Library at the Washington Navy Yard. At those institutions, a researcher can peruse an extensive collection of First World War naval documents selected by unnamed compilers. Immediately, the massive scope of the project becomes clear. Less apparent are the financial, professional, and political obstacles that ultimately contributed to the "Official Records" never reaching the printing press and the efforts of Captain Dudley Knox and the Historical Section that nearly overcame them. Captain Knox's fifteen years' leadership of "Official Records" salvaged a doomed project, provided future historians and researchers access to a valuable collection of naval records, and witnessed his emergence as a historian.

The documentary project's origins date from 22 June 1918, after the War Department asked the Navy Department to collaborate on a general staff history of

The Northern Mariner/Le marin du nord, XXVII, No. 1 (Jan. 2017), 15-30. 
the war. ${ }^{1}$ In response, Secretary of the Navy Josephus Daniels created an historical section under the chief of naval operations. ${ }^{2}$ Daniels established the office to collect documents in preparation for the naval volumes of the proposed general staff history. Daniels selected Rear Admiral (ret.) William W. Kimball to head the new section in Washington. Secretary Daniels encouraged his subordinates to collect materials related to the war but was reluctant to sacrifice any personnel from the war effort for that purpose. ${ }^{3}$ As a result, the collection of documents related to the conflict did not commence in earnest until the 11 November 1918 armistice. Following the end of fighting Chief of Naval Operations Admiral William S. Benson ordered Vice Admiral William S. Sims, commander of US forces in European waters, to form an historical section of his own at his London headquarters to work in concert with the section in Washington. ${ }^{4}$ Sims, who did not wait for the CNO's order, had already selected Knox to head the London section. ${ }^{5}$

\footnotetext{
${ }^{1}$ Newton Baker, Secretary of War to Josephus Daniels, Secretary of the Navy, Washington, District of Columbia, 3 June 1918; Historical Section, Box 675, Entry 464B, Subject File, 19111927; Naval Records Collection of the Office of Naval Records and Library, Record Group 45; National Archives Building, Washington, DC, [hereafter Archives I]. For the earlier origins of institutional military and naval history in the First World War see Elizabeth Drewry "Historical Units of Agencies of The First World War." Bulletins of the National Archives 4 (July 1942), 61. William Dudley "World War I and Federal Military History" The Public Historian 12:4 (Fall 1990), 23. Ronald Spector "An Improbable Success Story: Official Military Histories in the Twentieth Century" The Public Historian 12:1 (Winter 1990), 25. Benjamin Cooling "History Programs in the Department of Defense" The Public Historian 12:4 (Fall 1990), 43.

2 Opnav to Simsadus, Washington, DC, 22 June 1918, Historical Section, Box 675, Entry 464B; RG 45, Archives I; Josephus Daniels to William Kimball, Washington DC 22 June 1918, C-306, Box 46, Entry 58, Office of Naval Records and Library Correspondence Files, 1913-1925, Records of the Office of the Chief of Naval Operations, Record Group 38, Archives I.

${ }^{3}$ Daniels, "Collection of data for incorporation in a history of the US Navy in the War with the Central Powers," Historical Section, Box 675, Entry 464B, RG 45, Archives I.

${ }^{4}$ Vice Admiral William S. Sims, Commander of US Naval Forces in European Waters, to forces, "Historical sketch of activities during the war," London, United Kingdom, 20 November 1918, and Benson to Simsadus, Washington, DC, 12 December 1918, ibid.

${ }_{5}^{5}$ Sims sent requests for specially trained historical personnel to constitute a section as early as July and warned the Department that the work could not be adequately carried out by his staff. Sims was also a strong proponent of the navy commissioning trained historians performing historical work. The suggestion resulted from a study by Lt. Tracy Kittredge (USN London historical section) of the British historical section. Washington did not send Sims the required personnel during the war and decided that they could not assemble such a section after the Armistice. Sims to Benson "Memorandum concerning Naval Historical Section" London UK, 31 October 1918, C-6, Box 33, Entry 58, RG 38, Archives I. See also Drewry, "Historical Units."
}

The Northern Mariner/Le marin du nord, XXVII, No. 1 (Jan. 2017), 15-30. 
The importance Sims placed in the work of an historical section was clearly displayed by his selection of Knox. Knox had served on Sims' staff when the senior officer commanded the Atlantic Torpedo Flotilla from 1913 to 1915 and again when he was assigned as the president of the Naval War College in 1917. The force commander had specifically requested Knox's services early in the war and assigned him to his planning section in London. Sims would later describe Knox as "the Navy's leading authority on the all important questions of organization, administration, and, greatest of all, the art of leadership." "When Benson requested the recall of three members of the planning section to form his own section in Washington, Sims acquiesced to all named except Knox, about whom he successfully lobbied the CNO to retain for historical work. ${ }^{7}$ While not a trained historian, Knox provided the section administrative acumen, a broad knowledge of the navy and intellectual excellence. He also was a firm believer in the relevance and importance of history in addressing contemporary naval problems. ${ }^{8}$ He studied the British historical section under Sir Julian Corbett and implemented a replica of its archival system that filed records first by record type, then by geographical area, and finally by chronology. ${ }^{9}$ The system formed the basis of Knox's archival scheme for the next twenty years.

By 18 December 1918 Sims assigned Knox ten officers, and the number swelled to approximately thirteen in addition to about one hundred clerks, all diverted from US Navy offices in London. In an undated document, Knox provided London section's outline of work, stating that its "ultimate mission" was producing a professional critical analysis of United States naval operations in the war, to be preceded by simple historical narratives related to the navy's participation in the conflict. The third and final item listed in the outline, was to "collect data and arrange them... in a form convenient for the historian." ${ }^{10}$ He considered the act of collecting historical materials important primarily in its utility for assisting future navy historians in writing their narratives, rather than preserving the materials themselves. Despite Knox's apprehension of duplicating the effort of his counterparts in Washington, his section forged ahead to outpace the expanding demobilization of the European force. ${ }^{11}$ In mid-1919, the staff was reduced to five officers and twenty clerks, who finished the project several months later. The office

\footnotetext{
${ }^{6}$ Sims to Colonel Thomas T. Knox, Washington, DC 12 March 1920, Knox, Dudley, Box 128, Biographies, ZB File, Navy Library, Washington Navy Yard.

7 Sims to Admiral William S. Benson, Chief of Naval Operations, London, UK, 25 November 1918, NA-1 Knox Capt. Dudley W. Personal File, Box 349, Entry 520, RG 45, Archives I.

${ }^{8}$ See David Kohnen $21^{\text {st }}$ Century Knox: Influence, Sea Power, and History for the Modern Era. (Annapolis, MD: Naval Institute Press, 2016 ) for an excellent and in depth study of Knox's belief in the utility and importance of history.

9 Captain Dudley Knox, Chief of Historical Section London, "Memorandum," Washington, DC 12 December 1918, C-306, Box 46, Entry 58, RG 38, Archives I.

${ }_{10}$ Knox "Historical Section" London, UK, Box 1, Entry 517, Area File 1911-1927, RG 45, Archives I.

${ }^{11}$ Knox to Captain C.T. Vogelgesang, London, UK, 11 December 1918, C-6, Box 33, Entry 58, RG 38, Archives I.
} 
examined documents contained in approximately one hundred large metal filing cases of four drawers each and retained enough material to fill twenty. ${ }^{12}$ The section shipped these papers to Washington along with a portion of its personnel and effectively disbanded. Knox detached in March 1919 and served on the staff of the Naval War College and, one year later, took command of the cruiser Brooklyn.

The Washington Historical Section under Rear Admiral Kimball was not nearly as productive. The department was not forthcoming with personnel, including the trained historians requested by Kimball. ${ }^{13}$ The navy assigned the retired admiral, who was accustomed to commanding entire squadrons of modern warships, a staff of two clerical workers and an office in a storage space deep in the Main Navy Building. Even after the Office of Naval Intelligence loaned the section a large clerical staff following the armistice, he grew increasingly frustrated at the perceived lack of support and direction from the Navy Department, proclaiming to Benson that "Without the support of the Department my work in the Section is useless." "14

In addition, ships and stations were not forwarding historical materials to the Washington office, further frustrating the admiral and making archival work difficult. While Knox was implementing an entire archival system in London, in Washington Kimball lamented "there is nothing to do but dig into the Department's files, higglety pigglety." 15 He unsuccessfully attempted to interest both Captain Knox and Vice Admiral Sims in sharing some of his responsibilities and from November until May sent the CNO three requests for detachment from what he termed, "a futile pretense of what a real Historical Section must be." "Finally detached in May, Kimball offered the department three possible courses of action in a final memo, "(a)The present force can be employed in the unsatisfactory work it is now doing (b) The force can be cut down to any degree (c) The Historical Section may be abolished."17 Rear Admiral Kimball was succeeded by Captain Charles C. Marsh on 19 May 1919.

To resolve the personnel issues, the Navy Department prepared a provision for fiscal year 1920 appropriation bill which would allow for the new section to replace the temporary employees with a permanent staff. The first official to request funds for the project was Assistant Secretary Franklin D. Roosevelt. He was well known as a naval history enthusiast and had a personal interest in the publication of naval

\footnotetext{
12 Sims to Daniels, Newport, Rhode Island, 20 July 1919, C-6, Box 33, Entry 58, RG 38, Archives I.

13 Kimball to Benson "Memorandum," Washington, DC, 1 July 1918, ibid. Kimball continually requested trained historians based on the suggestions of Lieutenant Tracy Kitteredge's study of the British historical section.

${ }^{14}$ Kimball to Benson "Request for detachment from duty," Washington DC, 4 November 1918, C-

17, Box 34, ibid.

15 Kimball to Knox, Washington DC, 3 January 1919, Box 33, ibid.

${ }^{16}$ Kimball to Benson "Request for detachment from duty," Washington DC, 4 November 1918, C17, Box 34, ibid.

${ }_{17}$ Kimball to Rear Admiral Albert Parker Niblack, Director of Naval Intelligence, Washington DC, 15 May 1919, C-24, Box 34, ibid.
} 
documents, including the navy's first documentary history project The Official Records of the Union and Confederate Navies in the War of the Rebellion that had been underway since 1894 and remained unfinished in 1918. Urging Captain Marsh in 1919 to complete the Civil War volumes Roosevelt stated "I would hate to go out of office, as I shall do soon, with the feeling that during seven or eight years as Assistant Secretary of the Navy, not a single volume of the Naval War Records has been published." 18

Roosevelt met with the House Subcommittee for Appropriations on 10 December 1918. The assistant secretary argued that the congressional appropriation would allow the Navy Historical Section to collect and safeguard First World War records. The section would publish a documentary history after completing the collection and later produce an official history. Roosevelt requested \$25,000 with $\$ 5,000$ earmarked to hire a well-known historian. ${ }^{19}$ The representatives, however, introduced the bill on the floor that cut the appropriation to $\$ 20,000$ and stipulated that no employee could be hired above the salary of $\$ 1,800 .{ }^{20}$ At the time the average salary of a professor at a large university with over 1000 students enrolled was $\$ 3,632$. Overall the average pay for a professor was $\$ 2,784 .{ }^{21}$ A maximum salary of $\$ 1,800$ stemmed from representatives understanding of archival work as clerical in nature. Attempts by the Senate to amend the provision to Secretary Daniels's specifications failed in conference. ${ }^{22}$ When the bill, H.R. 14078 became law on 1 March 1919 it read,

Toward the collection or copying and classification with a view to publication, of the naval records of the war with the central powers of Europe, including clerical services in the District of Columbia or elsewhere, preparation of maps and illustrations, and other necessary incidental expenses, \$20,000: Provided, That no person shall be employed hereunder at a rate of compensation exceeding $\$ 1,800$ per annum. ${ }^{23}$

\footnotetext{
${ }^{18}$ Franklin D. Roosevelt, Assistant Secretary of the Navy, to Captain Charles Marsh, Officer-inCharge Historical Section, Washington DC, 8 December 1919, N.D. Asst. Sec. 249:104-, Box 17, Entry 57, RG 38, Archive I. Volume 26 and 27 were published during Roosevelt's term, so it is unclear if he is confused or referring to Series II.

19 Legislative, Executive, and Judicial Appropriation Bill, 1920: Hearing Before Subcommittee Of House Committee On Appropriations. $65^{\text {th }}$ Congress, 758(1918) available from: LexisNexis ${ }^{\circledR}$ Congressional.

${ }^{20}$ Union Calendar No. 319: H.R. 14078 In The House Of Representatives January 10, 1919. $65^{\text {th }}$ Congress, 81 (1919) available from: LexisNexis ${ }^{\circledR}$ Congressional.

${ }^{21}$ United States. Bureau of Labor Statistics. (1929). Handbook of labor statistics, 1929 edition, (Washington: US Government Printing Office), 834.

${ }^{22}$ Legislative, Executive, and Judicial Appropriation Bill, 1920: Hearings Before The Subcommittee Of The Committee On Appropriations United States Senate, $65^{\text {th }}$ Congress, 22. (1919). Conference Report: Legislative, Executive, And Judicial Appropriation Bill, $65^{\text {th }}$ Congress, 1. (1919) available from: LexisNexis ${ }^{\circledR}$ Congressional.

231920 Legislative, Executive, and Judicial Appropriation Act (H.R. 14078), available from: LexisNexis ${ }^{\circledR}$ Congressional.
} 
The language of the appropriation would hamstring efforts of the Historical Section to publish World War related histories for much of the next decade. The congressionally imposed salary cap made hiring a civilian historian, a course of action that was unanimously supported by Navy officials, effectively impossible. Perhaps more damaging for the long-term well being of the section, however, were the five words "with a view to publication." While having no true legal power, the phrase would annually draw the attention of appropriations committees and force the Historical Section and its successors to defend archival work essential to the project.

Rear Admiral Kimball's successors, Captain Charles C. Marsh and Captain William D. McDougall, continued his program with greater success. On 1 July 1919 the Historical Section merged with the Office of Naval Records and Library, the office that produced the Civil War documentary history. Although the section became a division of the office, the officer in charge of the Historical Section sat as chief of the merged organizations and managed the separate appropriations for both. The section was composed of three reserve officers serving as managers and sixteen clerical staff. Both Marsh and MacDougall unsuccessfully asked Congress to strike the salary cap clause in order to hire a civilian historian. Documents arrived in large numbers after Daniels named the section the "the depository for all files and all other material," and ordered ships and stations to send their materials to the office. ${ }^{24}$ Nonetheless, accession was gradual and with historical materials still sparse, the section focused on interim writing projects and a popular history of the war published under Secretary Daniels's name. Employees were also inundated with inquiries related to settlement of claims related to the war. Toward the end of MacDougall's tenure he told Congress that the Historical Section filed 90,000 documents since its inception. Many times more remained unprocessed and sixtythree large boxes, derived from the twenty file casess Knox collected in London, were still stored in navy's Bellevue Arsenal. In Captain MacDougall's final days in office, ten more large boxes arrived from various stations. He estimated that the project would involve the processing of approximately 800,000 documents. ${ }^{25}$

Captain Knox's arrival on 23 July 1921 was, in part, the result of a personal setback. A selection board twice passed over promoting him from temporary captain to permanent rank due to health problems and a perceived lack of sea-time. Unwilling to serve under as many as fifty former juniors, Knox asked for shore duty

\footnotetext{
${ }^{24}$ Daniels to Commanders of all Bureaus, Fleets, and Stations, "Collection of data for incorporation in a history of the US Navy in the War with the Central Powers," Washington DC, 13 June 1919, Historical Section, Box 675, Entry 464B, RG 45, Archives I.

25 "The Historical Section", Washington DC, August 1921, NA-1 Knox Capt. Dudley W. Personal File, Box 349, Entry 520, RG 45, Archives I. Navy Department Hearings Before The Subcommittee Of House Committee On Appropriations, 65th Congress, 917, (1920) available from: LexisNexis ${ }^{\circledR}$ Congressional.
} 
on the retired list. ${ }^{26}$ He received both requests and succeeded Captain MacDougall as head of the Office of Naval Records and Library and the Historical Section. In December 1921, Knox laid out his vision for the office for Assistant Secretary of the Navy Theodore Roosevelt Jr. He stated that the historical section would shift its focus to archiving the records of the World War. ${ }^{27}$

While building an extensive archival collection was the section's initial task, Captain Knox made clear that its goals involved publishing. Following the collection phase, the office would publish volumes of selected documents from the finished archives, and would pursue a more selective documentary edition than was earlier undertaken for the Civil War records. He still planned to complete an official history of the navy's involvement in the war, and framed the writing project as the distillation for public consumption of all of the navy's records, not just those selected for the documentary edition. To achieve these goals efficiently, Knox wrote Roosevelt that his staff needed to be doubled and one or more civil historians hired. In addition, he asked the navy to extend the terms of the section's reserve officer managerial force past a 1 July 1922 expiration of a congressional statute authorizing their assignment. Roosevelt responded with his agreement on all items and promised to support legislation for the section. ${ }^{28}$

In a period of financial retrenchment, a fiscally conservative Congress derailed many of Knox's initiatives and left him fighting for his section's existence. Knox battled the impending loss of three reserve officers from the first months after his arrival. In September 1921 the navy transferred most enlisted men and officers of the naval reserve to inactive, non-pay, status as a cost saving measure. ${ }^{29}$ The reservists under Knox were initially spared due to specific language of the 1920 statute at large that allowed for three reservists in the section until 1 July 1922. Retaining the reservists would have required changes in language of the naval appropriation bill. Despite enlisting the support of senators, the secretary of the navy, and the director of naval intelligence, Congress did not implement Knox's desired amendments, and on 1 July 1922 the Historical Section lost its entire managerial staff. ${ }^{30}$

\footnotetext{
${ }^{26}$ Knox to Captain Philip Williams, Bureau of Navigation, Monterey, California, 29 July 1921, Knox, Dudley, Box 128, Biographies, ZB File; Knox to Selection Board, "My selection for Promotion," San Peidro, California, 29 April 1921,Knox, Dudley, Box 128, Biographies, ZB File, 5; Knox to Admiral Robert E. Coontz, Chief of Naval Operations, Monterey, California, 29 June 1921, Knox, Dudley, Box 128, Biographies, ZB File, Navy Library.

${ }^{27}$ Knox to Theodore Roosevelt Jr., Assistant Secretary of the Navy, Washington DC, 19

December 1921, Historical Section, Box 675, Entry 464B, RG 45, Archives I.

${ }^{28}$ Ibid.

${ }^{29}$ Congressional Hearing, Naval Affairs "To Provide For The Creation, Organization, Administration, And Maintenance Of A Naval Reserve And A Marine Corps Reserve," US House of Representatives, 24 March 1922;,C-306, Box 37, Entry 58, RG 38; Knox to Captain Luke McNamee, Director of Naval Intelligence, "Memorandum for Captain McNamee," 22 April 1922, Entry 58, RG 38, Archives I.

${ }^{30}$ Knox, "Memorandum" Washington DC, 1 July 1922, C-306, Box 46, Entry 58, RG 38, Archives I.
} 
Before the fates of Knox's reservists were finalized, however, the House of Representatives threatened the very existence of the Historical Section. The problem resulted from the captain's 28 November 1922 meeting with the House Subcommittee on 1924 Navy Department appropriations. The committee seemed predisposed against the World War project. Subcommittee Chairman Patrick Kelley (R-Michigan) began the testimony on the issue, asking "These were to be finished up last year, were they not, Captain?" Knox corrected the record and estimated that the project would take fourteen years at the section's current staff levels. The Congressmen bristled at the figure, and ranking Democrat James Byrnes (D-South Carolina) quipped, "You will not get these finished up in time for the next war." Representative Kelley pressed Knox to publish, asking incredulously "You really must get the whole history before you start publication?" The committee struck the appropriation for the naval records of the World War following the hearing. ${ }^{31}$ Ostensibly they believed that the Historical Section was duplicating the historical work done by the Bureau of Navigation, the navy bureau in charge of personnel issues, related to its work compiling rosters of personnel engaged in the war for pension purposes. ${ }^{32}$

With his section facing elimination at the end of the 1923 fiscal year, Captain Knox revealed one of his greatest strengths; a keen ability to identify and enlist the support of powerful allies. In 1922 the most powerful historian in government was Senator Henry Cabot Lodge, a Harvard $\mathrm{PhD}$ who had led the charge against Woodrow Wilson and Article X of the League of Nations three years before. On 15 December 1922, as Knox was preparing for a hearing in front of the Senate subcommittee to discuss the omission of the Historical Section's appropriation, he penned Senator Lodge and appealed to his "personal interest in the welfare of the Historical Section," to ask for assistance. ${ }^{33}$ Lodge responded on the day of the 19 December hearing, promising to take the matter up with the committee. ${ }^{34}$ The senator kept his promise. As Knox justified his office at the hearing, senators chimed in to support him. After the senators asked their final question, the assistant secretary of navy was surprised at how rapidly the testimony proceeded. ${ }^{35}$ Two days later, a committee member wrote Senator Lodge "We have taken care of the appropriation... in a way that will I think be entirely satisfactory to Captain Knox." ${ }^{36}$

\footnotetext{
${ }^{31}$ Navy Department Hearings Before The Subcommittee Of House Committee On Appropriations, $67^{\text {th }}$ Congress, 886. (1922) available from: LexisNexis ${ }^{\circledR}$ Congressional.

${ }_{32}$ Navy Department Appropriation Bill 1924: Hearings Before The Subcommittee Of the

Committee On Appropriations United States Senate, $67^{\text {th }}$ Congress, 42. (1922) available from: LexisNexis ${ }^{\circledR}$ Congressional.

${ }^{33}$ Knox to Senator Henry Cabot Lodge, Washington DC, 15 December 1922, C-306, Entry 58, RG 38, Archives I.

${ }^{34}$ Lodge to Knox, Washington DC, 19 December 1922, C-306, Entry 58, RG 38, Archives I.

${ }_{35}$ Navy Department Appropriation Bill 1924: Hearings Before The Subcommittee Of the

Committee On Appropriations United States Senate. $67^{\text {th }}$ Congress, 42. (1922) available from: LexisNexis ${ }^{\circledR}$ Congressional.

${ }^{36}$ Senator Frederick Hale to Lodge, Washington DC, 21 December 1922, C-306, Entry 58, RG 38, Archives I.
} 
When the bill became law on 1 July 1924 it included the provision to fund the documentary project.

While struggling to keep the congressional appropriation for his section on the books, Knox also came up against the budgetary constraints of conservative Republican presidential administrations. As the administration sought to enforce peacetime budgets, the additional appropriations Captain Knox requested continually ran afoul of the Department of the Treasury's Bureau of the Budget. Congress created the bureau as part of the Budget and Accounting Act of 1921. The body determined which executive agency appropriation requests and expenditures were agreeable to the president and his financial program and could be brought before Congress. ${ }^{37}$ Captain Knox first was rejected by the Bureau of the Budget in 1922 while attempting to double the size and budget of his section. He argued that a large staff would complete the project more efficiently and save the government money in the long run. The plan was approved by the secretary of the navy, but was rejected by the bureau when submitted as not being consistent with President Warren G. Harding's policies. When meeting with Congress in November 1922, Representative Kelley asked Captain Knox if he could make do with fewer employees. Knox replied "I tried to get more, but I am not allowed to ask for more." ${ }^{38}$ The bureau refused nearly all of the section's requests for increased funding throughout the post-war decade, even for replacing attrition of employees or allocating more funds for needed promotions.

Captain Knox's administrative acumen allowed the Historical Section to overcome chronic personnel and funding shortages and make steady progress toward building a large archival collection. After losing his reservists in 1922, he promoted four civilians to supervisory roles and received one active duty officer to act as a deputy. The supervisors led four divisions for World War records: accession, archive, print and library. Beginning in 1923, a fifth division, records, processed documents of conflicts previous to the World War. The records division operated alongside with the World War sections throughout the inter-war period, arranging documents primarily from the eighteenth and nineteenth centuries.

Captain Knox split the archival work into four processes: selection, classification, indexing, and filing. The accessions division would select documents of historical value to send to the print division. Like Corbett before him, Knox stipulated that selections should be operational in nature with documents relating to logistics only retained when they were important to understand operations. The print division reviewed the selected documents, and made a second selection for the future documentary project and indexed all documents. The two divisions routed rejected documents to the head clerk and Captain Knox for final oversight before being boxed up for storage at Bellevue Naval Arsenal.

\footnotetext{
37 The Bureau of the Budget is the predecessor of the Office of Management and Budget (OMB).

${ }^{38}$ Navy Department Hearings Before The Subcommittee Of House Committee On Appropriations, $67^{\text {th }}$ Congress, 886. (1922) available from: LexisNexis ${ }^{\circledR}$ Congressional.
} 
Following selection, the archive division would classify the files into the same archival system Captain Knox learned from the British. ${ }^{39}$ Employees filed war diaries in class 1 , special reports including serial collections by subject in class 2 , general correspondence chronologically in class 3 , and cables and telegrams in class 4. The archives eventually merged classes 3 and 4 and sorted the documents into eleven geographical areas corresponding to theatres of the naval war, called the "area file." This file would serve the basis of the documentary history. The archive and print divisions would cooperate to produce an index and the archive division would file selected documents away.

The system was simple and scalable. It allowed the Historical Section to proceed despite personnel shortages which enabled Captain Knox to assign additional help easily if it ever became available. Knox's foresight was rewarded in 1927 when Congress merged the appropriations for the Historical Section and the Office of Naval Records and Library and he was easily able to transfer a portion of the latter's to World War work. Following the system, the Historical Section was able to build an extensive archival collection and a selective documentary history edition nearly simultaneously.

As the Historical Section processed documents, Captain Knox updated Congress annually on its progress. Following the turbulent hearings in 1922, the House Subcommittee on Naval Appropriations developed a more cordial rapport with Captain Knox under Chairman Burton French (R-Idaho). The improved relationship did not translate into any substantial gains for the section but neither did the committee threaten the Historical Section's existence. The representatives also continued to interpret the work of the section as having to do with the eventual publication of an official history. Consistently Knox would finish his opening remarks and questioning would begin with Representative French asking for an estimate as to when the section would start publishing. The representatives also continually expressed confusion over the difference between the roster of personnel kept by the Bureau of Navigation and the work of the Historical Section. After Knox cleared up confusion and provided yearly estimates, the committee routinely appropriated the section funds approved by the Bureau of the Budget. These appropriations remained stagnant and diminished toward the end of the decade. The combined 1920 appropriation for the Office of Naval Records and Library and World War Records was $\$ 41,000$, by the 1928 appropriation bill the combined offices received $\$ 37,940$ from Congress. ${ }^{40}$ This was despite a 26 percent increase in the average national wage during that period. ${ }^{41}$

The Navy Department supported the section throughout the decade, and by the end of 1925 assigned two retired officers to augment its management. Despite that

\footnotetext{
39 Knox, "Major Processes" Washington DC, 8 November 1922, C-306, Entry 58, RG 38, Archives I.

${ }^{40}$ Captain J.W. McElroy, Office of Naval Records And Library 1882-1946. Washington DC. 1 June 1946. Accessed on the Naval History and Heritage Command Website, 3 April 2016.

${ }^{41}$ Handbook of labor statistics, 1931 edition, (Washington: US Government Printing Office), 849.
} 
support, Knox confided in a history professor at the Naval War College, "It can hardly be said that at any time the department's attitude toward the section was highly favourable. On the other hand, it has never been unfriendly. It is characterized more by a passive interest than anything else. Most people in the department believe that we should have a Historical Section but in very few quarters is there more than an academic interest in it." ${ }^{, 2}$ Certainly, the navy did not have the desire to press Knox's suggestions through opposition in the Bureau of the Budget or marshal support in Congress. Thus, the archival process crept along steadily, adhering to the organization and workflow instituted by its leader.

As the end of the decade approached, the House of Representatives began to lose patience with the project. By 1928 work had progressed to a stage where Knox estimated completion of the archival phase in three years. This fact remained unknown to the House Committee on Naval Affairs when the Bureau of Navigation chief, Rear Admiral Richard Henry Leigh, a former colleague from London, testified in front of the body on 21 May 1928. Leigh's testimony, dealing with personnel levels in the service, was largely a matter of routine until he mentioned the topic of Captain Knox and the two retired officers in his section. Upset because they perceived the pay of the retired officers was too high, and, according to Leigh, the work had continued for ten years, the representatives asked him how long the project would last. The bureau chief responded that he didn't know "because they don't tell me when they are going to quit." Leigh, forced to discuss a topic that he knew little about and seemingly misunderstood, later threw gas on the fire, and stated definitively that Knox initially estimated assembling the history for publication would take three years, a claim that does not match documentary records. Representative Carl Vinson (D-Georgia) asked "When will the public read it?" to which the committee chairman, Representative Frederick Britten (R-Illinois), interjected "This public will not. Their children will." Britten then proclaimed "If they don't have it in 10 years, they will not have it in a hundred and ten years. There is something wrong with that organization; I am convinced of that." He threatened a congressional hearing on the subject. ${ }^{43}$

Language from Knox's subsequent letters suggest that reports of the hearing angered him. In addition to the personal nature of some of Britten's attacks, he insisted, with evidence from documentation that the information provided by Rear

\footnotetext{
${ }^{42}$ Knox to J.M. Scammell, Professor Naval War College, Washington DC, 25 January 1923, C306, Entry 58, RG 38, Archives I. In the letter the word "passing" is originally written but it was crossed out and changed to passive. Knox refers in this quote to the department after the end of Daniels tenure. In the same letter he characterizes the department under Josephus Daniels as unfriendly to the section, an opinion he inherited from both Kimball and Sims.

${ }^{43}$ A Hearing On The Bill (H.R. 13683) To Regulate The Distribution And Promotion Of Commissioned Officers Of The Line Of The Navy, And For Other Purposes, House Of Representatives, Committee On Naval Affairs, $70^{\text {th }}$ Congress, 3242 (1928) available from: LexisNexis ${ }^{\circledR}$ Congressional.
} 
Admiral Leigh's testimony was erroneous. ${ }^{44}$ The navy sided with Knox and in February the Committee on Naval Affairs published a summary of Captain Knox's services and the work of the Historical Section to correct the record. Still, pressure from the House mounted. In the 24 January 1929 House subcommittee meeting for the 1930 appropriation, Representative French stated "It seems to the members of the Committee that this work should be approaching an end." ${ }^{45}$

Fortunately for Captain Knox, the archive work was, in fact, approaching an end. By February 1929 the Historical Section processed and filed 400,000 World War documents into the archival collection and placed many times more in storage. On 13 June 1929 Secretary of the Navy David S. Ingalls forwarded proposed legislation, prepared by Knox, to the Bureau of the Budget for the publishing of the Official Records of the US Navy in the World War in thirty volumes at 800 pages each. The bill called for an annual allotment of $\$ 20,000$ to publish 10,000 copies of two volumes yearly. The secretary estimated that the ultimate cost of publishing the series would be approximately $\$ 280,000{ }^{46}$

After ten years of work and appropriations, the Bureau of the Budget rejected funds for publishing the navy's World War documentary history. On 28 June 1929 acting director of the Bureau of the Budget, Royal O. Kloeber, responded to Secretary Ingalls's proposed legislation, stating that the expenditures outlined in the proposed legislation were not in accord with the financial program of the president. ${ }^{47}$

An internal Bureau of the Budget document suggests that, in fact, the bureau's decision had little to do with the potential expenditures outlined by the navy alone. A memorandum prepared by bureau investigator Robert Adams recommended refusing the proposed appropriation to avoid incurring high costs of a potential army documentary history of the World War.

By 1929 the War Department was interested in publishing a documentary history as well. Unlike the navy Historical Section however, War Department historians spent the post-war decade focussed on writing monographs and analytical studies of American Expeditionary Force operations at the expense of collecting and arranging World War documents. ${ }^{48}$ When the War Department began contemplating their own archival project in 1928, the estimated 20,000,000 documents were in

\footnotetext{
${ }^{44}$ Knox, "Memorandum For Director Of Intelligence," Washington DC, 16 June 1928, Historical Section, Box 675, Entry 464B, RG 45, National Archives I.

${ }^{45}$ Navy Department Appropriation Bill For 1930: Hearing Before Subcommittee Of House Committee On Appropriations, $70^{\text {th }}$ Congress, 772 (1929) available from: LexisNexis ${ }^{\circledR}$ Congressional.

${ }^{46}$ David S. Ingalls, Secretary of the Navy, to Royal O. Kloeber, Acting Director of the Budget, Washington DC, 13 June 1929, "World War Records," Entry 7A General Subject File, Subject Files of the Director, 1921-1938, Records of the Office of Management and Budget, Record Group 51, National Archives at College Park, College Park, Maryland (NARA).

${ }^{47}$ Kloeber to Ingalls, Washington DC, 28 June 1929, "World War Records," Entry 7A, RG 51,NARA.

${ }^{48}$ Drewry, 12.
} 
poor condition and widely dispersed. ${ }^{49}$ The Bureau of the Budget forecast that collecting, arranging and publishing the War Department documents would cost an alarming $\$ 6,000,000 .^{50}$

On 18 June 1929, Adams reviewed the navy's 13 June submission, which was separate from any proposed legislation funding the War Department's project. ${ }^{51} \mathrm{He}$ focussed little on the figures provided by Knox and the secretary, only off-handedly observing that the navy's $\$ 280,000$ estimate could be low. Adams insisted, however, that the government could not publish navy documents without also agreeing to publish the documents of the War Department. Thus, the investigator suggested that printing navy documents would actually cost approximately $\$ 6,300,000$. In conclusion, Adams wrote "until the Government is willing to undertake... printing and distributing the official records relating to the participation by all military forces of the U.S... the matter should be held in abeyance." 52 Congress had pushed Captain Knox to publish since 1921, but when the section was ready, the bureau struck down the project to avoid favouring one service over the other.

Although he pared the proposed project down to twenty volumes, Captain Knox was similarly rebuffed by the bureau in 1930 and $1931 .^{53}$ The bureau's decision had tied the navy's proposed history to the astronomically more expensive army's in a time of economic turmoil. Legislation to obtain appropriations for the service's

\footnotetext{
${ }^{49}$ Public pressure applied primarily by historians and veterans groups through members of congress sought to compel the War Department and Navy Department to arrange and publish documents related to the war. The Department initially resisted this pressure, advising against two bills introduced in 1926 and 1927 for the purpose. The War Department's stance changed after a1928 Advisory Board of the Army War College ruled that the documents were widely disbursed and in deteriorating condition. The board recommended that the department focus on collecting of World War documents. When Congress ultimately did not provide appropriations for the project, the work of collecting World War documents fell to the existing historical section of the Army War College as their main focus. The section worked on the project through the Second World War, finishing the project in 1948 and Government Printing Office printed seventeen documentary volumes in 1949-1950 as The United States Army in the World War 1917-1919. Drewry, 12.

${ }_{50}$ The estimate resulted from expenses incurred during the publishing of The War of the Rebellion: a Compilation of the Official Records of the Union and Confederate Armies. After the army provided the Bureau of the Budget an estimate of $\$ 3,000,000$, the director of the bureau, Herbert $M$ Lord, estimated that when contemporary expenses were considered, the cost would surpass $\$ 6,000,000$. Herbert M. Lord, Director, Bureau of the Budget to W. Frank James, Chairman, House Military Affairs Committee, Washington DC, 28 February 1927, "World War Records," Entry 7A, RG 51, NARA.

${ }^{51}$ At the time House Joint Resolution 34, which sought appropriations for both the Army and Navy projects, was in front of the House Military Committee. The Navy's records were prepared for publishing and required much less of an appropriation than the Army's. The Navy submitted its own bill which was to be reviewed separately. "A bill" Washington DC, "Washington DC" Entry 7A RG 51. Ingalls to Kloeber 13 June 1929, ibid.

${ }_{52}$ Robert Adams, "Memorandum," Washington DC, 18 June 1929, ibid.

${ }^{53}$ Knox, "Memorandum For The Chief Of Naval Operations," Washington DC, 26 February 1931, Historical Section, Box 675, Entry 464B, RG 45, Archives I.
} 
documentary projects stalled three times in the House of the Representatives. ${ }^{54}$ The setbacks did not seem to worry Knox as his understanding of his section had largely changed. While his 1919 outline of work for the London historical section and his 1922 memorandum to Theodore Roosevelt Jr. described archival work as merely the first stage in a three stage process leading to a documentary series and an official history, in a May 1929 memo to his superiors, Knox wrote "The prime function of the Histor ical Section and the Office of Naval Records" was "the collection and archiving of historical sources of naval history." $" 55$

Ultimately, the promise of political cooperation, rather than political obstruction shelved the World War project. In 1932 the first man to discuss publically the idea of a naval documentary history on the World War was elected president of the United States. Franklin Roosevelt scheduled a meeting with Captain Knox within weeks of assuming office. In the White House, the president handed Knox a personal set of official documents he had retained from his time as assistant secretary of the navy. Roosevelt, however, had other documents in mind. After taking a keen interest in the affairs of the Historical Section, during which time he doubtlessly heard about the woes of the World War project, the president suggested that the Office of Naval Records and Library begin publishing early American naval documents instead. ${ }^{56}$ Knox was prepared for such a project as the records division had been processing early American naval documents since $1923 .{ }^{57} \mathrm{He}$ enthusiastically agreed to the president's plan.

Roosevelt's preference to defer the World War documentary series in favour of early naval documents initially seems peculiar, especially considering that on some level Roosevelt was responsible for the documentary series. Indeed, in 1934 the acting director of the Bureau of the Budget sought clarification from the president as to why the department was not publishing World War documents. ${ }^{58}$ Roosevelt's interest in publishing early naval documents over World War documents was multifaceted. He specifically mentioned the potential for controversy if the department published World War documents. Since Roosevelt's 1918 testimony, Vice Admiral Sims and Secretary Daniels had engaged in a bitter public dispute and the resulting congressional hearings and bad press. The president also developed the opinion that the World War occurred far too recently for the appropriate perspective to produce

\footnotetext{
${ }^{54}$ Representative Piatt Andrew sponsored the bills including House Joint Resolution 34 in 1929, and House Joint Resolution 17 in 1931.

${ }_{55}$ Knox to Director of Naval Intelligence, "Historical functions of the Navy Department," Washington DC, 6 May 1929 Historical Section, Box 675, Entry 464B, RG 45, Archives I.

${ }^{56}$ Knox, "Association with Franklin D. Roosevelt of Dudley W. Knox," Washington DC, 1948; A Memoir: Association with Franklin D. Roosevelt of Dudley W. Knox," Container 25, Dudley Wright Knox Papers, Manuscript Division, Library of Congress (LOC), Washington, DC. 57 Commander J.H. Sypher, Officer in Charge Navy Library, “Office Organization” 18 December 1923, C-306, Entry 58, RG 38, Archives I.

${ }_{58}$ D.W. Bell, Acting Director Bureau of the Budget, "Memorandum for the President," Washington DC, 21 February 1935, Addition, Photocopies from FDR Library, Container 24, Dudley Wright Knox Papers, Manuscript Division, LOC.
} 
a meaningful work of history. ${ }^{59}$ Knox and the president also viewed the early navy documentary histories as crucial to preserving the history contained in old, fragile documents and prioritized them over the decade-old World War materials. ${ }^{60}$ Finally, the decision was also strategic and political. Roosevelt desired to highlight the importance of funding a navy in peacetime, and the experience of the United States Navy in its undeclared wars against France and the Barbary Pirates around the turn of the nineteenth century illustrated the service's continued importance after a decade of relative neglect and disarmament. Captain Knox wholeheartedly supported this thinking. ${ }^{61}$ Captain Knox and President Roosevelt planned to return to the World War documents, but only after the office published seven other series.

The president took an active role in publishing the first two series of early American naval documents, The Naval Documents Related to the Quasi-War between the United States and France and Naval Documents Related to the United States Wars with the Barbary Powers. Knowing that funding proved to be a constant problem for the World War Project, the president suggested a \$10,000 revolving fund that would be used to publish the volumes and be replenished when the public purchased the books at cost. He also helped surmount Captain Knox's traditional antagonists in the Bureau of the Budget and Congress. On the eve of a budget hearing in 1935 related to the Quasi-war project, the president personally wrote the acting director of the budget "This is my pet child. Will you push the additional appropriation and try to make it a revolving fund?" 62 In a later memoir, Knox recalled that at one internal executive branch budget hearing related to the project he was grilled for half an hour by an official asking for specific details. At the end of the hearing the official smiled and explained "he had orders from the White House to give Dudley Knox all he asked for." ${ }^{\prime 3}$ Likewise, in 1934 the president personally contacted Representative James Byrnes, now chairman of the Subcommittee on Naval Appropriations to push the committee to fund the project. ${ }^{64}$ When the Government Printing Office published the first volume of Naval Documents Related to the Quasi-War between the United States and France in 1935, Captain Knox brought his copy to Roosevelt for his signature. After

\footnotetext{
59 President Franklin D. Roosevelt, "Memorandum for the Director of the Budget" Washington DC, 22 February 1935,Addition, Photocopies from FDR Library, Container 24, Dudley Wright Knox Papers, Manuscript Division, LOC.

60 Ibid.

${ }^{61}$ Kohnen,16.

62 President Franklin D. Roosevelt, "Memorandum for the Acting Director of the Budget" Washington DC, 12 February 1935, Addition, Photocopies from FDR Library, Container 24, Dudley Wright Knox Papers, Manuscript Division, LOC.

${ }^{63}$ Knox, "Association with Franklin D. Roosevelt of Dudley W. Knox," Washington DC, 1948; A Memoir: Association with Franklin D. Roosevelt of Dudley W. Knox," Container 25, Dudley Wright Knox Papers, Manuscript Division, LOC.

${ }^{64}$ Marvin H. McIntyre, Secretary to the President to Roosevelt, "Memo For The President," Addition, Photocopies from FDR Library, Container 24, Dudley Wright Knox Papers, Manuscript Division, LOC.
} 
considerable thought, the president signed "For Dudley Knox - in appreciation of a dream of yours and mine come true - Franklin D. Roosevelt." ${ }^{35}$

The "Official Records of the US Navy in the World War," never reached a publisher, but its legacy lived on through its patron, Captain Dudley Knox. Through a decade of crises and disappointments, Knox evolved from a gifted naval officer in charge of a history section to a bona fide historian. While the crucial work of archiving and preserving documents initially was a means to an end for Knox, by the 1930s he clearly understood that the historical process was equally as important as historical product. In addition, trained historians can learn a great deal from Knox and his use of simple and scalable processes that enabled him to tackle a massive project despite limited resources and support. With his new appreciation of history as a discipline, and his long-held organizational genius, Knox led the Office of Naval Records and Library for nearly three decades. During that time he published two documentary series and oversaw the collection of documents for an official naval history of the Second World War, among a long list of other important accomplishments. The navy's current historical organization, The Naval History and Heritage Command, appropriately remembers Knox as its institutional architect.

The World War section of the Office of Naval Records and Library persisted throughout the 1930s in an archival function. The section revisited the logistics papers earlier rejected, boxed, and housed in the Bellevue Arsenal. These files formed the basis of many of the bureau records currently at the National Archives. The operational files collected by the office now form the bulk of record group 45 at the same institution. Researchers can view the documents originally selected to form the World War documentary history in Entry 517B within record group 45 or microfilmed at the Naval Library at the Washington Navy Yard. The Naval History and Heritage Command recently initiated a World War I Documentary History Project to commemorate the centennial of the United States entry into World War I. The selected documents that Dudley Knox personally reviewed will form the backbone of an online documentary edition that will post its first documents in January 2017. Historians will expand upon Knox's vision, and provide documents of interest to a modern audience of researchers, sailors, and interested members of the public. Knox worked against heavy odds to provide an important source of naval history for future generations, the Historians of the Naval History and Heritage Command are honoured to carry on his important work.

\footnotetext{
${ }^{65}$ Knox, "Association with Franklin D. Roosevelt of Dudley W. Knox," Washington DC, 1948; Container 25, Dudley Wright Knox Papers, Manuscript Division, LOC.
} 